\title{
Local Culture-based Storybook and Its Effect on Reading Competence
}

Ni Made Ratminingsih

Dr., English Language Education, Ganesha University of Education, Bali, Indonesia, made.ratminingsih@undiksha.ac.id

\section{Gede Budasi}

English Language Education, Ganesha University of Education, Bali, Indonesia, gede.budasi@undiksha.ac.id

\section{Wira Dharma Asha Kurnia}

English Language Education, Ganesha University of Education, Bali, Indonesia, wiradharmaasha@gmail.com

Reading is the basic literacy as the foundation for intellectual development. Researchers found that Indonesian students have low reading competence. This is due to the fact that they do not possess a good reading habit. Hence, the study aimed at investigating the effect of local culture-based storybooks, one of which is a fable on students' reading competence and analyzing the effect size of the treatment. It was an experimental research administering post-test only control group design. The population was sixth grade students of elementary schools in Buleleng Regency, Bali. The samples were determined using intact group cluster random sampling technique of 34 students from two elementary schools. Experimental group was treated by using storybook, whereas control group was taught by using text-based story. The data were collected through post-test. The obtained data were analyzed descriptively and inferentially using t-test. Cohen's d was administered to check the effect size. The result proves that there was a significant effect of local culture-based storybook on students' reading competence, while Cohen's d shows that the effect size was medium. Thus, teachers are recommended to regularly use stories for improving reading competence.

Keywords: fable, local culture, reading competence, storybook, reading

\section{INTRODUCTION}

Reading is one of four language skills that must be mastered by students. A good reading skill is regarded as the foundation of obtaining knowledge and the basis of academic achievement. However, reading is a complex process. Kamhi and Catss

Citation: Ratminingsih, N. M., Budasi, I. G., \& Kurnia, W. D. A. (2020). Local Culture-based Storybook and Its Effect on Reading Competence. International Journal of Instruction, 13(2), 253268. https://doi.org/10.29333/iji.2020.13218a 
(2005:3) state that reading is a complex cognitive activity, associated with skill in comprehending texts. It is complex because there are several things to possess to comprehend a text, such as adequate knowledge of words, grammar which influences the ability to grasp the meaning of sentences, and sufficient knowledge of contents or general knowledge related to the contents of reading. In order to comprehend a text, at least there are two main processes, bottom up and top down (Brown, 2001). Through bottom up process, readers need to understand the language from the smallest parts (data-driven) starting from sounds, morphemes, syllables, words, phrases, sentences, grammar, and cohesive devices before understanding the overall text, while through top down process (conceptually-driven), they should use their intellectual capacity and experience to understand it. The main purpose of reading is to construct meaning of the text based on the visual perception made by the readers (Erbeli \& Pizorn, 2013). Thus, a good reading competence is needed to achieve the purpose of reading. Teodorescu (2006) specifies that competence covers skill and knowledge required to achieve critical completion. Hence, reading competence is the knowledge and skill possessed for successful reading.

Several researchers show that Indonesian students have lack of reading competence. Greenery's reports entitled "Literacy Standards in Indonesia" (cited in World Bank's report, 1998) indicated that the ability to read of elementary school students at sixth grade was scored 51.7. It was the last position after Philippines with score 52.6, Thailand with score 65.1, and Singapore with score 75.5. This reflects Indonesian elementary school students were the lowest in their reading competence compared to those from other ASEAN countries. More current data from PISA in 2015 revealed that Indonesian students achieved mean score 397 for reading. However, it is still below the standard of OECD mean score for reading that is 493. The latest research conducted by Central Connecticut State University (CCSU, 2016) in World's Most Literate National Ranks analyzed large-scale trends in literate behavior and literacy in more than 60 countries. Based on this study, Indonesia took the 60th position among 61 nations in the world. In addition, an international student reading' achievement was published by The International Association for the Evaluation of Educational Achievement (IEA, 2011) in International Reading Literacy Study (PIRLS). It demonstrated an assessment of reading for sixth grade students among 45 countries. In this study, Indonesia gained score 428 (4.2) and it was significantly lower than the center point of PIRLS scale which was 500. Those data indicate that Indonesian students have a serious problem in reading. More specifically, on the perspective of elementary students in Bali, Yogantari and Wilani (2018) report that the students' low reading ability was caused by several factors, namely low reading interest which derived from less interesting books used by the teachers, lack of teachers' teaching competence, and less relevant teaching strategies implemented in teaching.

A continuous enhancement of reading competence should be given an intensive focus, starting from the elementary until tertiary level. Specifically, students, who are classified as young learners, have particular characteristics in their learning. They hardly learn from abstraction. According to Piaget (as cited in Slavin, 2008, pp. 45-54), young learners are under concrete operational stage where they need objects and experienced 
situation to learn better. In order to facilitate their needs, an appropriate teaching media is required. Ratminingsih (2016) conveys that numerous and skillful uses of media can help learning material more interestingly appeared and more easily transferred. They will lead to the contextual teaching and learning. Berns and Erickson (2001) state that in a contextual teaching and learning there is a connection between content and the real situation, prior knowledge, new knowledge, and its application. Therefore, to bring a contextual teaching and learning, local culture-based content is used. Relevant local culture gives positive influence toward learning (Cobern \& Aikenhead,1996; Wahyudi, 2007). The local culture has functioned as media and learning stimuli to motivate and help students construct new knowledge (Suardana, et al., 2018). Suardana, et al. (2018) further prove that the critical thinking skills of the students who learned through the local culture-based learning model were better than those obtained by the students who learned through the discovery learning model. Alwasilah (2004) also emphasizes that by adopting local culture in EFL, it improves motivation and sensitivity towards the culture itself.

Teachers should be aware of promoting positive emotions during learning to motivate the students to get involved and be responsible with their learning. Meng and Wang (in Ebrahimi, et al. 2018) also argue that language learning could be facilitated by positive emotions and it also improves language performance. Positive emotions include adaptability and stress management. Adaptation done in this research is by presenting the existing local culture-based story into the learning of English in which the level of difficulty of the story is reduced by making it more appropriate for young learners. While stress is managed and decreased by the familiarity of the story which is closed to their life and the existence of contextualization and visualization of the story through the use of pictures. Both adaptability and stress management are parts of emotional intelligence which according Ebrahimi, et al. (2018) could develop reading skill.

The storybook is used to provide the local culture-based content for their learning to read. This is due to the significant role of storybook in EFL context for a long time (Karabacak \& Erdem, 2015). Additionally, storybook has the power of covering text and pictures (Khotimah, 2010) which leads to visual literacy (O’Neil, 2011). Furthermore, Woolley (2011) affirms that there is a connection between the visual mental model the reader constructs and the visual information from the pictures in the text. Therefore, the use of storybook in reading, supported by text and pictures may construct a stronger mental model. Students will not only imagine a vocabulary by their perception, but also pictures help them to have a clear vision about it. Moreover, the involvement of local culture makes a contextual learning for them as it deals with something close to their life, therefore it can improve their reading competence.

Several previous studies investigated the use of storybook. Anderson and Balandin (2011) proved that storybook could accommodate children with a range of literacy, cognitive, attentional, and psychosocial needs. Van Der Pol (2012) demonstrated that children who read the twenty-four picture books with the literary conversations showed a significant improvement in literary competence compared to those in the control 
groups. Blamey, Beauchat, and Sweetman (2012) confirmed that teachers could develop children's vocabulary development during storybook reading more often. In addition, Lee (2015) observed 39 Taiwanese adult EFL learners' responses toward reading children's literature and found that the use of children's literature could improve their English language competence, confidence, and also motivation. The authentic illustrated storybook made language learning fun so that they enjoyed their learning. The study also concluded that this kind of storybook is appropriate for beginners or struggling readers. Mihai, Friesen, Lieber, and Palmer (2015) focused their study on one important early literacy skill, phonological awareness. It described how to support its development for all children by intentionally involving it in storybook reading. The result was that teaching phonological awareness through storybook reading provided a meaningful context for children to not only appreciate books but also to develop an awareness of sounds in the environment, words, syllables, rhyme, onset-rimes, and phonemes. Restanto (2016) justified that picture book plays an important role in helping students learning to read narrative with more than $50 \%$ responses were positive. In line with it, Roslina (2017) investigated the effect of storybooks on the students' reading comprehension and explained the perception of students on the use of storybooks in teaching reading. The result indicated that it improved students' reading and interest. Moreover, it has an effect on the students' reading comprehension (the value is 0.025 ) with higher scores in the post-test.

Considering those previous theoretical and empirical reviews, the aim of this study is mainly to investigate the significant effect of local culture-based storybook on students' reading competence. Meanwhile, the goal of this study is actually to justify whether or not this kind of storybook has an impact on reading competence in particular and basic literacy in general. As well it is also aimed to preserve the local culture which exists in the society.

\section{Research questions}

1. Is there any significant effect of local culture-based storybook on students reading competence?

2. To what extent is the effect size of local culture-based storybook on students reading competence?

\section{LITERATURE REVIEW}

\section{Reading Competence}

Competence has a broad definition. It covers specific range of knowledge, skills, or ability. According to Teodorescu (2006), competence covers skill and knowledge required to achieve critical completion. Richards and Rodgers (2003) elaborate that competence refers to a description of essential skills, knowledge, attitudes, and behaviors required for effective performance of real world tasks. Additionally, Moghabghab, et al. (2018) define competence as an individual capability for consistently integrating the required knowledge, skill, and judgement for safe, ethical, and effective practice. Therefore, competence can be defined as individual capability 
which covers specific knowledge, skills, attitudes, and behaviors which are necessary to perform meaningful and effective practice or performance.

Reading competence in particular is therefore the knowledge and skills required to comprehend text based on specific components. Erbeli and Pizorn (2013) divide reading competence into three components such as phonological, orthographic, and vocabulary knowledge. Phonological component refers to awareness or reader's sensibility for the phonological structure of words. It is related to word recognition skill and reading. Orthographic component deals with word recognition that affects a fast and effective reading fluency. Moreover, vocabulary knowledge component makes a good reader because a good reader always has a larger range of vocabulary knowledge. Vocabulary knowledge is a very important component because it affects the level of reader's comprehension by knowing meaning of each word. Furthermore, Grabe (in Ediger, 2001, p.154) describes that there are six components of skills and knowledge identified in reading activity. Those are automatic recognition skill which refers to subconscious ability involving mental process to identify words, adequate knowledge of vocabulary and grammar, knowledge of the structure of formal discourse, knowledge of contents or general knowledge, skills in analyzing and synthesizing, and metacognitive knowledge and monitoring skill. Therefore, reading is a complex process which involves several components. In order to help students in their process of reading, Brown (2001) formulates three phases of reading, namely before reading, during reading, and after reading. Before reading, teachers may give opportunity for students to recognize the topic, encourage students to use skimming, scanning, and predicting, and activate their schema to help them easily comprehend the text. During reading, teachers should guide the students to understand facts and rhetorical devices in order to comprehend the text. After reading, students are given comprehension questions dealing with the text. Follow up activities after reading which should be paid attention to by the teachers are vocabulary reviews, author purpose, discussion on author reasonings, review on grammatical structure, and writing practices.

\section{The Insertion of Local Culture in EFL}

Local culture is a culture that exists in a specific area. Sudartini (2012) defines that local culture is a term closely related with tradition or form of attitude containing many ways of thinking and act, derived from inherited norms and customs. Every place on earth has its own culture that is different from one another. Local culture is a certain culture that exists in a particular place, owned by a particular society (Ratminingsih \& Budasi, 2018). The existence of local culture in each area will be beneficial for its devotee. It is because the local culture reflects the personality of its society, in terms of way of life and belief, which are used to observe the outside world in daily life (Savitri, Batan, \& Ratminingsih, 2016). Parmini (2015) clarifies that local culture contains cultural values that are advantageous for character education and protection of the local culture itself. In this study, the local culture involved is Balinese culture. Suwardhani (2015) adds that Balinese culture is categorized as an expressive culture because it covers some values that reflect the culture itself such as aesthete, religion, solidarity, and harmony. 
Local culture involvement in learning is important, especially in relation with reading and EFL. Giving texts containing local culture to students in reading class can be the approach to involve the students in the learning process (Royani, 2013). Sudartini (2012) states that the insertion of local culture in EFL can be an alternative way in preparing students' cultural background or identity that improves their awareness of nationalism when they learn foreign culture in practice of EFL. By inserting local culture in EFL, teachers can combine it with the learning of English. According to Yembise (2011), to develop students' communicative competence, the instructional material should be adjusted to their cultural aspects. Thus, students from elementary schools up to terteriary level of education should be given subjects on local culture. One of the instructional materials is story. Teachers believe that it will be easy for students to master English and make them comfortable in using new language because of the familiarity of the story (Prastiwi, 2013). In addition, local culture text makes students to start enjoy reading because the text is more understandable with the "authentic" one and local culture text will give an appropriate culture for the students (Royani, 2013).

\section{Storybook}

Storybook helps a lot to make students feel almost at the same situation as in the story, because according to Khotimah (2010), it is not only a written text, but also covers pictures and the story at once. It means that young learner can see visually the situation and develop their imagination. In line with it, Ratminingsih and Budasi (2018) state that storybook is a type of book that combines the use of text and image to present aesthetic value. In general, storybook consists of characters, plot, conflict, and resolution of the conflict (Kotaman \& Balci, 2017), which is presented with pictures.

Furthermore, storybook could give students authentic example of the use of vocabularies. Brewster, Ellis, and Girard (2002:188) explain that authentic storybooks provide examples of real language and offer a rich source of authentic input, especially in terms of vocabulary. Therefore, teachers must implement it carefully to students so that they can understand the use of vocabularies in the storybook. Malu (2013) argues that words alone are not enough for story to be understood, whereas the pictures alone only tell parts of story, so that the interaction between visual and verbal interaction can clarify it. By using storybook, students can be involved in a dialogue interactively during reading activity through dialogic reading (Ratminingsih \& Budasi, 2018). Moreover, Ratminingsih and Budasi (2018) clarify that students can visualize the characters and places being told in the storybooks and the vocabulary can be comprehended easily through pictures.

\section{Fable}

The type of storybook used in this study is a narrative text. The genre is a fable story entitled "Siap Selem". The word fable is from Latin word "fabula" which means "story" (Kayhan, Mohammadzadeh, \& Atmaca, 2017). In this kind of story, the characters are animals. They behave like humans who are able to think, interact, feel, and act. Kayhan, et al. (2017) further define that fable is a type of short story where the main characters are animals or plants and its purpose is to give a moral lesson. Fable is beneficial for 
teaching and learning process. Sujud, Rahim, and Affendi (2014) conclude that students are able to do word recognition by using fable in an interesting and fun way. Moreover, Rahmawati, Roekhan, and Nurchasanah (2016) describe that fable stories are often referred to as moral stories because the messages/values in the fable are closely related to morals. Besides, there is normally a strong connection between the fable, which is directed from local culture, and the students. Therefore, they will find it easier to learn by using local culture-based fable storybook.

\section{METHOD}

This was an experimental research applying post-test only control group design, which was conducted in elementary schools in Buleleng Regency in April until August 2018. The primary data were collected by delivering post-test of reading competence after the two groups were given different treatments. Prior to the treament, normality and homogeinity test to the two groups, experimental and control, were conducted which was further continued with t-test analysis of their English achievement taken from the summative test scores. This was done to ensure the two groups were insignificantly different before treatment.

\section{Population and Sample}

The population of this study was sixth grade students of elementary schools in Banjar District, Buleleng Regency, Bali. All groups of individuals in this population were taken because they shared some characteristics, such as they were in the same grade, they have not been taught by using local culture-based storybook yet, and they have learned English for a longer period (since the fourth grade).

There were two schools determined as the samples by conducting intact group cluster random sampling, SDN 1 Banjar and SDN 4 Temukus. After administering lottery, students of SDN 1 Banjar were defined as the control group and students of SDN 4 Temukus were treated as the experimental group.

\section{Instruments}

\section{Treatment instrument}

In giving treatment to students, the researchers used lesson plans to guide the process of teaching process. The lesson plans for three teaching sessions were different for both groups. The experimental group was taught by using local culture-based storybook delivered in dialogic reading technique, while the control group was taught by using conventional teaching media, namely text-based story, through translation, memorization, and reading comprehension questions.

Both the storybook and the script of text-based story have exactly the same contents, the difference lies only in terms of the presentation of the media. The storybook utilizes the combination of text and pictures, while the text-based story does not contain any pictures. Therefore, both media have similar characteristics in accordance to the use of language expressions, verbal and non verbal language, as well as the level of difficulty of the contents. 


\section{Data collection instruments}

The instrument used in collecting data was post-test in the form of reading test, such as multiple choice, matching, and completion. This main instrument underwent content validity by expert judgement before empirical validity. It was tried out to non-sample school, SDN 2 Paket Agung, to check the validity and reliability. The empirical validity was based on Biserial Point Formula and processed by using software named Microsoft Office Excel 2007. In measuring the empirical validity, the researchers used the tcritical value, which was compared to the t-observed to determine which item was valid or dropped. Those valid items were then measured by using Kuder-Richardson (KR) 20 formula in Microsoft Office Excel 2007. After all the items of the test fulfilling the requirement of the validity and reliability, the test was given to the students after delivering the treatments to both groups. It was administered in order to check the significant difference of reading competence between two groups.

\section{Technique of Data Analysis}

There were two kinds of data analyses, the first was descriptive statistics analysis and the second was inferential statistics analysis. In descriptive statistics analysis, the data were presented descriptively by measuring mean, median, mode, range, variance, and standard deviation. In inferential statistics analysis, the data were analyzed using independent sample t-test formula to determine whether or not there was a significant difference on students' reading competence being treated differently. Before measuring inferential statistics analysis, normality and homogeneity pre requisite tests were administered. The calculation was done by using SPSS 16. Afterwards, Cohen's $d$ effect size test was conducted to measure the effect size of the treatment.

\section{FINDINGS}

Based on the research problems stated previously, there are two main findings as presented below. First is the result of students' reading competence after being treated with local culture-based picture story books analysed using descriptive statistics and inferential statistics and second is the calculation of the effect size of the treatment.

\section{The Effect of Local Culture-Based Storybook on Students Reading Competence}

The result of students' post-test on reading competence is presented in table 1 .

Table 1

Students' Post-test Score Distribution

\begin{tabular}{llll}
\hline Control Group & & \multicolumn{2}{l}{ Experimental Group } \\
\hline Score & Frequency & Score & Frequency \\
\hline 100 & 2 & 100 & 4 \\
95 & 1 & 95 & 0 \\
90 & 2 & 90 & 3 \\
85 & 2 & 85 & 5 \\
80 & 0 & 80 & 2 \\
75 & 2 & 75 & 1 \\
70 & 5 & 70 & 2 \\
60 & 3 & 60 & 0 \\
TOTAL & 17 & TOTAL & 17 \\
\hline
\end{tabular}


Table 1 shows the post-test scores achieved by the students in both groups. The highest score of control group is 100 succeeded by 2 students, whereas the lowest score is 60 obtained by 3 students. On the other side, the highest score of experimental group is 100 reached by 4 students, whereas the lowest score is 70 attained by 2 students.

\section{Descriptive statistics analysis of students' reading competence}

The students' post-test scores used the same interval 0 to 100 , which were analyzed descriptively by using SPSS 16 . The analysis was mainly conducted to measure the central tendency covering mean, median, mode, range, standard deviation, and variance. The summary of descriptive analysis of students' post-test scores is presented on table 2 .

Table 2

Summary of the Descriptive Statistics Analysis Result

\begin{tabular}{llllllll}
\hline \multirow{2}{*}{$\begin{array}{c}\text { Post } \\
\text {-test }\end{array}$} & Group & Mean & Median & Mode & Range & Std. Dev. & Variance \\
\cline { 2 - 8 } & Control Group & 77.94 & 75 & 70 & 40 & 13.58 & 184.55 \\
\cline { 2 - 8 } & Experimental Group & 86.47 & 85 & 85 & 30 & 9.80 & 96.14 \\
\hline
\end{tabular}

Based on table 2, the mean score of control group is 77.94. On the other hands, the mean score of the experimental group is 86.47. In terms of median, the control group is 75 , while the experimental group is 85 . The mode of control group is 70 found in five students. Meanwhile, the mode of experimental group is 85 achieved by five students. This means that the experimental group outperformed the control group.

\section{Inferential statistics analysis of students' reading competence}

Before conducting inferential statistics analysis, pre-requisite tests were conducted, normality test and homogeneity test. The normality test used Saphiro-Wilk statistics, processed in SPSS 16.

Table 3

Normality Test

\begin{tabular}{|c|c|c|c|c|c|c|c|}
\hline & \multirow[b]{2}{*}{ Group } & \multicolumn{3}{|c|}{ Kolmogorov-Smirnov ${ }^{\mathrm{a}}$} & \multicolumn{3}{|c|}{ Shapiro-Wilk } \\
\hline & & Statistic & Df & Sig. & Statistic & $\mathrm{df}$ & Sig. \\
\hline \multirow{2}{*}{ Score } & Experimental Group & .151 & 17 & .200 & .913 & 17 & .114 \\
\hline & Control Group & .191 & 17 & .099 & .909 & 17 & .096 \\
\hline
\end{tabular}

a. Lilliefors Significance Correction

*. This is a lower bound of the true significance.

Based on table 3, the significance value (Sig.) of control group is 0.96 , while the significance value (Sig.) of the experimental group is 0.114 . Both groups achieve the significance value that is higher than the significant value (0.05). Therefore, the data are in normal distribution.

In determining whether or not the data is homogeneous, the significance value of Levene Statistic (Sig.) should be or exceed the significant value, that is 0.05 (5\%). The following table presents the result of homogeneity test by using SPSS 16. 
Table 4

Homogeneity Test

\begin{tabular}{llll}
\hline Score & & & \\
\hline Levene's Statistic & df1 & df2 & Sig. \\
\hline 3.841 & 1 & 32 & .059 \\
\hline
\end{tabular}

Based on table 4.8, the Levene Statistic significance value (Sig.) is .059. The significance value is higher than 0.05 . Therefore, the data are homogeneous. Since the data of both groups have been proven normally distributed and homogeneous, the data are, then, analyzed inferentially to test the hypothesis of the study.

Table 5

Independent Samples t-Test

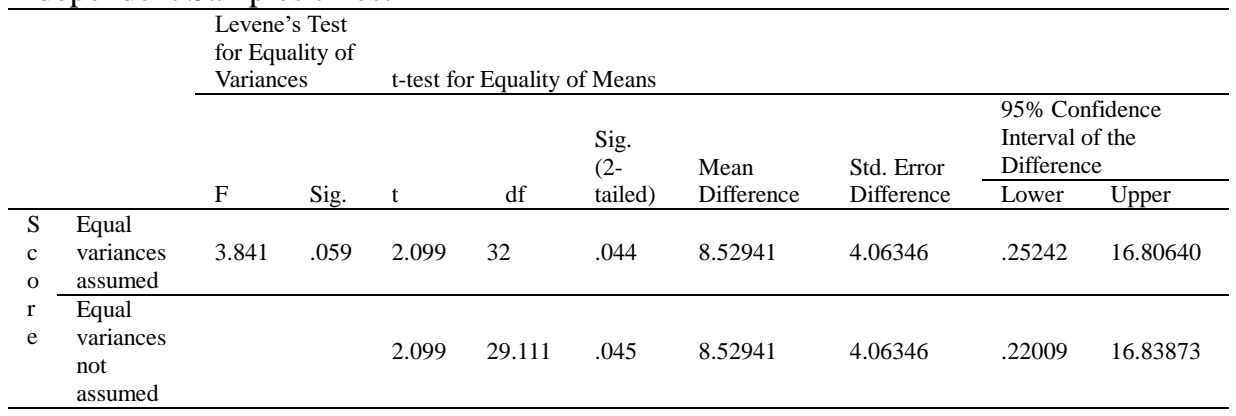

On table 5, the value of $t_{0}$ in equal variances assumed is 2.099 at the degree of freedom (df) 32. In comparison, the value of $t_{\mathrm{cv}}$ at the degree of freedom (df) 32 is 2.036. The value of $t_{0}$ is higher than $t_{c v}(2.099>2.036)$. Thus, based on the criteria of determining significant difference, the difference of the mean score of the samples is significant and alternative hypothesis $(\mathrm{Ha})$ is accepted. Therefore, by comparing it to the qualification for determining the hypothesis in t-test, there is a significant effect of storybook on students' reading competence, in which the difference lies on the presentation forms of the story, namely storybook and text-based story.

\section{The Effect Size of Students' Reading Competence}

The effect size was calculated by using the Cohen's $d$ formula as follows.

$$
\begin{aligned}
& d=\frac{M_{\text {group 1 }}-M_{\text {group2 }}}{S D_{\text {pooled }}} \\
& d=\frac{M_{\text {group 1 }}-M_{\text {group2 }}}{\sqrt{\left(S D_{\text {group 1 }}^{2}+S D_{\text {group 2 }}^{2}\right) / 2}} \\
& d=\frac{86.47-77.94}{\sqrt{\left(9.80^{2}+13.58^{2}\right) / 2}}
\end{aligned}
$$

International Journal of Instruction, April $2020 \bullet$ Vol.13, No.2 


$$
\begin{aligned}
& d=\frac{8.53}{\sqrt{(96.04+184.42) / 2}} \\
& d=\frac{8.53}{\sqrt{280.46 / 2}} \\
& d=\frac{8.53}{\sqrt{140.23}} \\
& d=\frac{8.53}{11.84} \\
& d=0.72
\end{aligned}
$$

The result of Cohen's $d$ value reaches 0.72 . Based on the Cohen's d effect size criteria (table 6), the value is higher than 0.50 and lower than 0.80 . Therefore, the effect of using local culture-based storybook is still categorized medium. However it closely approaches 0.80 which means that there is a tendency of obaining large effect size if the treatment is continued.

Table 6

Criteria of Cohen's d Statistics

\begin{tabular}{ll}
\hline Values & Interpretation of Effect Size \\
\hline 0.20 & Small effect size \\
0.50 & Medium effect size \\
0.80 & Large effect size \\
\hline
\end{tabular}

\section{DISCUSSION AND CONCLUSION}

The finding of the study proves that there is a significant different effect on students' reading competence being treated differently. The experimental group got higher posttest mean score than the control group. This is due to the fact that pictures in the storybook helped students to visualize the story so that they were easier to understand it. It is in line with Woolley (2011) that the visual mental model the reader constructs is connected with the visual information from the pictures in the text. In addition, students can imagine the characters and places in the storybooks and the vocabulary can be understood easily through pictures (Ratminingsih \& Budasi, 2018). In this study, the storybook constructed a stronger visual mental model for experimental group, while on the contrary text-based story did not provide the support of pictures to the control group. Students in experimental group did not only imagine a vocabulary by their perception, but also pictures which guided them to have a clear vision about it. Thus, students in experimental group achieved a better comprehension of the story. Moreover, Piaget (as cited in Slavin, 2008:45-54) emphasizes that young learners require the existence of objects and experienced situation to learn better. This statement clearly signifies that students learn better because they got pictures as the objects in reading to explain the vocabularies. This research finding is in accordance with Restanto (2016) that proves pictures help students to improve their reading. Besides, it is also consistent with 
Roslina (2017) that the storybook makes the students interested in reading, therefore they are able to achieve better reading comprehension. Furthermore, the use of dialogic reading also contributed to students' better involvement during reading the storybook. Ratminingsih and Budasi (2018) justify that students involved in a dialogue interactively during reading activity could achieve a better understanding of the story.

The combination between pictures and text presented in the storybook was helpful for the students to comprehend the text. Malu (2013) states that words alone are not enough for story to be understood, while the pictures alone only tell parts of story, so that the interaction between visual and verbal interaction can clarify it. Then, the use of the storybook in experimental group gives a better impact because it presents the visual and verbal interaction to students. Ratminingsih and Budasi (2018) convey that students can visualize the characters and places being told in the storybook and the vocabulary can be comprehended easily through pictures. During reading activity, when the students did not recognize the meaning of a vocabulary, the pictures available in the storybook could guide the students to its meaning. For example, when the students did not know the character named I Doglagan, the picture of the chick without fur could explain what it looked like. This is also supported by O'Neil (2011) who asserts that in visual literacy there is an interaction, called reinforcing, which means the existence of picture supports the reader by providing more details or description. Thus, they can develop their understanding of the story better since the pictures help them to comprehend the vocabulary. This finding is in correlation with Blamey, et al. (2012) that storybook is good for vocabulary development. It improves reading interest and comprehension (Roslina, 2017), language competence (Lee, 2015), and particularly literary competence (Van der Pol, 2012).

Another interesting finding is that the insertion of local culture could help the students to easily understand the content of the story. Both groups, experimental and control eventually found that learning English containing Balinese local culture was easier. This finding supports Ratminingsih and Budasi (2018), Yembise (2011), and Alwasilah (2004) that the existence of local culture in English instruction supports the contextual learning because it is close to the students' life. Prastiwi (2013) emphasizes that because of the familiarity of the story, it will be easy for students to master English and make them comfortable in using new language. Alwasilah (2004) adds that adopting local culture in English enhances motivation of young learners to read. This finding is also in agreement with previous researches that local culture stimulates and motivates students to build their knowledge (Cobern and Aikenhead,1996; Wahyudi, 2007; Lee, 2015; Suardana, et al., 2018). This strengthens the reason why students, either experimental group or control group, were enthusiastic and active in learning to read the local culture-based story entitled "Siap Selem".

Meanwhile, text-based story is different from the picture storybook because it is a scriptprinted text without pictures which was given to the control group. During reading activity, translation technique was used to help the students to comprehend the text. Ratminingsih (2013) explains that in Grammar Translation Method (GTM) students learn to read and write in native language accurately. Thus, when they did not know the 
meaning, they were provided directly with the accurate meaning in their native language while reading. They were also given reading comprehension questions during reading and after reading orally to check their comprehension on the story. Most of them were able to answer the questions correctly. This finding affirms Ratminingsih (2013) that GTM is still good enough for developing students' comprehension because they learn more to read with the assistance of students' native laguage. When some difficult words in the story were translated, some of them wrote the meaning on the text. Therefore, they could memorize the vocabulary.

In accordance with the result of effect size, it shows a medium to nearly large effect. This might be due to the fact that both groups learned reading material with similar local culture contents, which differs only in the forms of presentation, one with colourful pictures in the storybook, while another one without pictures. Regardless of the different forms, Royani (2013) in this case affirms that local culture text makes students to start enjoy reading because the text is more understandable. During the study, translation technique administered to the control group could help them to understand the meaning of the vocabulary to support reading comprehension. Their activity in taking notes could support their memorization. In relation to this, Ratminingsih (2013) confirms that memorization is used to make students' vocabulary broader. Students who took note might have learned more about the meaning of vocabularies. Although the effect size is medium, the result shows that there is a tendency to reach the large effect size which reflects that the present of pictures in the storybook is more effective to enhance students' reading competence.

Taking into consideration all the findings above, it could be summed up that there is a significant effect of local culture-based storybook, which is presented by combining pictures and text, on students' reading competence. Thus, it can be justified that the different performance of the media has a different impact on the students' reading competence. This study implies that it is an effective media which is recommended to be used to contextualize the language teaching and learning. This contextualization can ease the students in their process of reading comprehension. Besides that, familiarization of the contents by introducing local culture makes reading more understandable, thus the students can improve their reading competence. In addition, the existance of pictures in the storybook makes reading activity more interesting, so that they are encouraged to have fun reading which leads to higher reading competence.

\section{ACKNOWLEDGEMENTS}

The authors would like to thank the Ministry of Research, Technology, and Higher Education of Indonesia for granting the research schema to conduct this study. They also address their gratitude to Rector of Undiksha via Institute of Research and Community Service of Undiksha to facilitate the study. Additionally, they also express their thank to school principals, teachers, and students of SDN 1 Banjar and SDN 4 Temukus, Buleleng Regency for their permission and cooperation during the research administration. 


\section{REFERENCES}

Alwasilah, A. C. (2004). From local to global: Reinventing local literature through English writing classes. TEFLIN Journal, 17(1), 11-27.

Anderson, K., \& Balandin, S. (2011). The storybook method: Research feedback with young participants. Augmentative and Alternative Communication, 27(4), 279-291.

Berns, R. G., \& Erickson, P. M. (2001). Contextual teaching and learning: Preparing students for the new economy. NCCTE, 5, 1-8.

Blamey, K. L., Beauchat, K. A., \& Sweetman, H. (2012). Vocabulary instruction through storybook reading. NHSA Dialog, 15(3), 260-265.

Brewster, J., Ellis, G., \& Girard, D. (2002). The primary English teacher guide. London: Penguin

Brown, H. D. (2001). Teaching by principles: An interactive approach to language pedagogy. New York: Addison Wesley Longman, Inc.

CCSU. (2016). World's most literate national ranks. Retrieved from http://webcapp.ccsu.edu/?news=1767\&data.

Cobern, W. W., \& Aikenhead, G. S. (1996). Cultural aspects of learning science. Retrieved from http://wmich.edu/slcsp/121.HTML.

Ebrahimi, M. R., Khoshsima, H., \& Zare-Behtash, E. (2018). The impacts of enhancing emotional intelligence on the development of reading skill. International Journal of Instruction, 11(3), 573-586.

Ediger, A. (2001). Teaching children literacy skills in a second language. In M. CelceMurcia, (Ed.), Teaching English as a second or foreign language. Boston, M. A.: Heinle \& Heinle, a division of Thomson Learning.

Erbeli, F., \& Pizorn, K. (2013). The structure of reading competence in English as a foreign language. Journal of Contemporary Educational Studies/ Sodobna Pedagogika, 64(1), 44-58.

IEA. (2011). Progress in international reading literacy study 2011 (PIRLS). Retrieved from https://timssandpirls.bc.edu/pirls2011/downloads/P11_IR_Chapter1.pdf.

Kamhi, A. G. \& Catts, H. W. (2005). Language and learning disabilities. Boston: Allyn \& Bacon.

Karabacak, K., \& Erdem, S. (2015). The effect of using English story books in English courses by adapting them to different activities on the foreign language success of the students. Procedia-Social and Behavioral Sciences, 176, 1028-1033.

Kayhan, H., Mohammadzadeh, B., \& Atmaca, S. (2017). The use of fables in science laboratory. Eurasia Journal of Mathematics, Science and Technology Education, 13(8), 4471-4480. 
Khotimah, M. K. (2010). Upaya peningkatan kemampuan membaca melalui metode bercerita storybook reading (Penelitian tindakan kelas di BA Aisyiyah Waru 03 Baki Sukoharjo) (Unpublished doctoral dissertation). Universitas Muhammadiyah Surakarta.

Kotaman, H., \& Balci, A. (2017). Impact of storybook type on kindergarteners' storybook comprehension. Early Child Development and Care, 187(11), 1771-1781.

Lee, H. (2015). Using picture books in EFL college reading classrooms. The Reading Matrix, 15(1), 66-77.

Malu, K. F. (2013). Exploring children's picture storybooks with adult and adolescent EFL learners. English Teaching Forum, 51(3), 10-18.

Mihai, A., Friesen, A., E., Lieber, J., \& Palmer, S. (2015). Teaching phonological awareness to all children through storybook reading. Young Exceptional Children, 18(4), 3-18.

Moghabghab, R., Tong, A., Hallaran, A., \& Anderson, J. (2018). The difference between competency and competence: A regulatory perspective. Journal of Nursing Regulation, 9(2), 54-59.

OECD. (2015). PISA 2015 results in focus. Paris. OECD.

O’Neil, K. E. (2011). Reading pictures: Developing visual literacy for greater comprehension. The Reading Teacher, 65(3), 214-223.

Parmini, N. P. (2015). Eksistensi cerita rakyat dalam pendidikan karakter siswa SD di Ubud. Jurnal Kajian Bali 5(2), 441-460.

Prastiwi, Y. (2013). Transmitting local cultural knowledge through English as foreign language (EFL) learning as a means of fostering "Unity in Diversity". Academic Journal of Interdisciplinary Studies, 2(3), 507-513.

Rahmawati, I. S., Roekhan, R., \& Nurchasanah, N. (2016). Pengembangan media pembelajaran menulis teks fabel dengan macromedia flash bagi siswa SMP. Jurnal Pendidikan: Teori, Penelitian, dan Pengembangan, 1(7), 1323-1329.

Ratminingsih, N. M. (2013). Teaching English as a foreign language 1. Singaraja: Undiksha Press.

Ratminingsih, N. M. (2016). Developing an audio media with scripted songs and its effect: A way out for fun learning for TEYL. In The 61 TEFLIN International Conference, 976-979.

Ratminingsih, N. M., \& Budasi, I. G. (2018). Local culture-based picture storybooks for teaching English for young learners. In SHS Web of Conferences, 42, 00016.

Restanto, M. (2016). The use of picture book in teaching reading for junior high school students. Journal of English and Education, 4(2), 49-62.

Richards, J. C., \& Rodgers, T.S. (2003). Approaches and method in language teaching. Cambridge: Cambridge University Press. 
Roslina. (2017). The effect of picture story books on students' reading comprehension. Advances in Language and Literary Studies, 8(2), 213-221.

Royani, M. (2013). The use of local culture texts for enthusiastic English reading teaching. The International Journal of Social Sciences, 7(1), 130-135.

Savitri, P. W., Batan, G., Ratminingsih, N.M. (2016). Developing a local culture-based picture storybook in the form of fable for teaching English for young learners (Unpublished undergraduate thesis). Universitas Pendidikan Ganesha.

Slavin, R. E. (2008). Psikologi pendidikan (M. Samosir, Translation). Jakarta: Indeks.

Suardana, I. N., Redhana, I. W., Sudiatmika, A. A. I. A. R., \& Selamat, I. N. (2018). Students' critical thinking skills in chemistry learning using local culture-based 7E learning cycle model. International Journal of Instruction, 11(2), 399-412.

Sudartini, S. (2012). Inserting local culture in English language teaching to promote characters education. Jurnal Pendidikan Karakter, 1, 54-54.

Sujud, A., Rahim, N. A., \& Affendi, N. R. N. M. (2014). Word recognition through Malay animal fables. Asian Social Science, 10(11), 252-257.

Suwardhani, N. P. (2015). Pewarisan nilai-nilai kearifan lokal untuk memproteksi masyarakat Bali dari dampak negatif globalisasi. Jurnal Kajian Bali, 5(2), 247-264.

Teodorescu, T. (2006). Competence versus competency: What is the difference? Performance Improvement Journal, 45(10), 27-30.

Van der Pol, C. (2012). Reading picture books as literature: Four-to-six-year-old children and the development of literary competence. Children's Literature in Education, 43(1), 93-106.

Wahyudi (2007). Kurikulum IPA berbasis budaya lokal. Retrieved from http://www.duniaguru.com.

Woolley, G. (2011). Reading comprehension: Assisting children with learning difficulties. New York, NY: Springer.

World Bank. (1998). Education in Indonesia: From crisis to recovery. Retrieved from http://documents.worldbank.org/curated/en/558971468752104023/Indonesia-Educationin-Indonesia-from-crisis-to-recovery.

Yembise, Y. S. (2011). Linguistic and cultural variations as barriers to the TEFL settings in Papua. TEFLIN Journal, 22(2), 201-225.

Yogantari, L. P. W., \& Wilani, N. M. A. (2018). Pengaruh teknik mnemonik terhadap kemampuan membaca aksara Bali pada siswa kelas III Sekolah Dasar Negeri 1 Batubulan. Jurnal Psikologi Udayana, 5(3), 755-770. 